\title{
Recovery of Neurological Injury in Patients with Thoracolumbar Spine Fracture Relevant to the Fracture Pattern
}

\author{
ESSAM Kh. EL-SHERIEF, M.D.; HASSAN M. ALI, M.D.; KHALED M. HASAN ALI, M.D. and \\ ANDREW Th. NASEEF, M.Sc.
}

The Department of Orthopedics and Traumatology, Assiut University Hospital, Assiut, Egypt

\begin{abstract}
Background: Thoracolumbar fracture is the most common skeletal injury of the axial skeleton and accounts for around $90 \%$ of all spinal fractures. Spinal cord injury occurs in about $10-30 \%$ of traumatic spinal fractures. Many studies included age of the patients and initial canal compromise as variables associated with neurological recovery after neurologic injury with spinal fracture but little documentation in the literature is found on the relationship between fracture patterns assessed by $\mathrm{AO}$ classification and neurologic recovery.
\end{abstract}

Aim of Study: To analyze the relationship between fracture patterns according to AO classification and neurological recovery in patients with thoracolumbar spine fracture who underwent transpedicular screw fixation with or without canal decompression.

Patients and Methods: The 60 patients ( 38 men and 22 women) in this series had a follow-up of 12 months, and they were all managed surgically. AO classification had been used prospectively to determine the fracture pattern. Frankel scale was obtained before surgery, after surgery and at the final follow-up.

Results: AO-type B fractures were the commonest. The degree of neurologic deficits seen at admission was the greatest in AO-type $\mathrm{C}$ and the least in AO-type A while at final followup it was greatest in AO-type $\mathrm{C}$ and least in AO-type $\mathrm{B}$. The neurologic recovery was the best in AO-type $\mathrm{B}$, assessed by Frankel grading. The neurologic recovery was greater in the lumbar spinal fractures than the thoracic spinal fractures.

Conclusions: In conclusion, there is a significant relation between the $\mathrm{AO}$ classification fracture pattern and neurological insult and the percentage of neurological recovery. The fracture level is correlated with the percentage of neurological recovery. There is no relation between the degree of canal compromise and the pre-operative neurological deficit in patient. The percentage of neurological recovery is relatively better in patients undergo canal decompression compared with those don't.

Key Words: AO classification - Thoracolumbar spine fracture - Neurologic deficits - Frankel classification.

Correspondence to: Dr. Essam Kh. El-Sherief, The Department of Orthopedics and Traumatology, Assiut University Hospital, Assiut, Egypt

\section{Introduction}

THORACOLUMBAR fracture is the most common skeletal injury of the axial skeleton and accounts for around $90 \%$ of all spinal fractures [1] Spinal cord injury occurs in about $10-30 \%$ of traumatic spinal fractures [2]. Traumatic spinal cord injury is estimated to be $29-50$ cases per million populations per year worldwide. The life expectancy for subjects with spinal cord injuries is shortened by 15-20 years compared with uninjured control subjects [3]. Spinal cord injury happen due to destruction from direct trauma, compression by bone fragments, hematoma, or disk material and ischemia from damage or impingement on the spinal arteries [4].

Several studies assessed some of the variables associated with neurological recovery after neurologic injury with spinal fracture, such as the age of patients, the level of lesion, initial canal compromise, initial posttraumatic kyphosis, timing of operation, amount of canal decompression and treatment method [5-7]. Although there is little documentation in the literature on the relationship between fracture patterns assessed by AO classification and neurologic recovery [8].

\section{Patients and Methods}

\section{Patient demographics:}

The study is a prospective study that is conducted in the Trauma Unit of Assiut University Hospital and included 60 patients with thoracic, thoracolumbar and lumbar spine fractures combined with neurologic deficit and treated with transpedicular screw fixation in the Emergency Department from January 2016 till June 2017. The 60 patients ( 38 men and 22 women) in this series had a followup of 12 months. The average age at the time of 
operation was 34.18 years, ranging from 16 to 60 years. The cause of injury was a fall from the height in 27 patients $(45 \%)$ and automobile accident in 19 patients $(31.7 \%)$. Other causes accounted for injury in 14 patients $(23.3 \%)$.

\section{Patient evaluation:}

All patients were assessed for back pain evaluation by Visual Analogue Scale [9] (VAS).

Neurological evaluation was done preoperatively, post-operatively and at follow-up visits according to Frankel classification [10]. The Frankel grade was exchanged numerically and analyzed. For example Frankel grade A was changed as 1 and Frankel grade $\mathrm{E}$ as 5 . The percentage of neurologic recovery was defined as the "actual neural recovery" (final follow-up score minus preoperative score) divided by the "potential neural recovery" (maximal score minus preoperative score).

Plain radiographs and computerized tomography scans were obtained in all cases. The fractures were classified according to AO classification [11] Fracture of L 1 vertebra was the most affected level. The extent of spinal canal compromise was measured using computed tomography with a slice thickness of ( 3 or $5 \mathrm{~mm}$ ). The least mid-sagittal diameter of the spinal canal at the level of injury was measured. The mid-sagittal diameter of the original spinal canal was estimated by calculating the mean of corresponding measurements at the un-injured adjacent levels above and below the injured vertebra. The percentage of spinal canal compromise at presentation was calculated using the formula: $a=(1-X / Y) 100$ ( $a=$ percentage of canal compromise, $\mathrm{X}=$-mid-sagittal diameter ofthe spinal canal at the level of injury, $Y=$ mean of the midsagittal diameters of the spinal canal one segment above and below the level of injury [12] Fig. (1). Functional evaluation at follow-up visits was done using oswestry disability index [13]

(A)

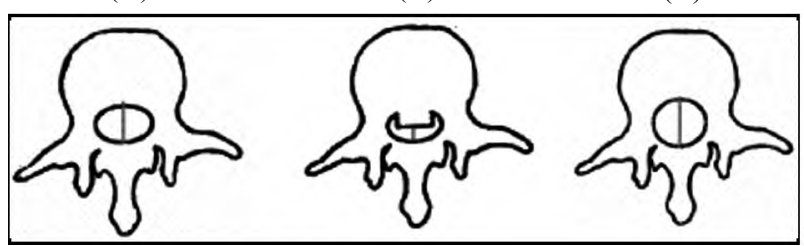

$\operatorname{MSD}(\%)=\{1-(\mathrm{B} /[(\mathrm{A}+\mathrm{C}) / 2])\} \times 100$

Fig. (1): Illustration of checking (MSD) of fracture vertebra.

\section{Operative technique:}

Direct decompression by laminectomy was done for fractures with reversed cortical sign or in case of entrapment of the root or dural sac by split laminal fracture. Other than that ligamentotaxis was done.

Thirty seven patients $(61.7 \%)$ underwent long segment TPSF and 23 patients $(38.3 \%)$ underwent short segment TPSF. Decision was done depending on load sharing fracture classification [14]. Long segment TPSF was done for the patients with score $\geq 7$.

\section{Statistical analysis:}

A two-tailed $p<0.05$ was considered statistically significant. All analyses were performed with the IBM SPSS 20.0 software.

\section{Results}

According to Frankel classification, preoperative neurological status was grade $\mathrm{A}$ in 16 patients (26.7\%), B in $10(16.7 \%), \mathrm{C}$ in $22(36.6 \%)$ and $\mathrm{D}$ in $12(20 \%)$. At last follow-up visits, it was $\mathrm{A}$ in 10 patients $(16.7 \%), \mathrm{B}$ in $3(5 \%), \mathrm{C}$ in 10 $(16.7 \%), \mathrm{D}$ in $30(50 \%)$ and $\mathrm{E}$ in $7(11.6 \%)$. Thirty nine patients of $60(65 \%)$ improved at least one grade of Frankel classification. The total percentage of neurologic recovery was $34 \%$.

Only two patients $(3.3 \%)$ presented with type A while type B was the most common type (75\%). Type (B 1) was the most common subtype. While type $\mathrm{C}$ cases represented 13 patients out of 60 $(21.6 \%)$ (Table 1).

Back pain, according to VAS score, improved significantly from $(8.96 \pm 0.80)$ pre-operatively to $(3.28 \pm 1.42)$ at last follow-up visits $(p<0.001)$.

Functional assessment of patients, according to ODI, showed 30 patients $(50 \%)$ were with minimal or moderate disability. Twenty patients (33.3\%) were with severe disability and the remaining $10(16.7 \%)$ were crippled or bed bound.

Table (1): Distribution of fracture pattern according to AO classification.

\begin{tabular}{ccc}
\hline AO classification & No. & $\%$ \\
\hline$A:$ & 2 & 3.3 \\
A2 & & \\
$B:$ & 24 & 40.0 \\
B1 & 20 & 33.3 \\
B2 & 1 & 1.7 \\
B3 & & \\
$C:$ & 13 & 21.7 \\
C & 13 & \\
\hline
\end{tabular}


Relation between AO fracture pattern and neurological status:

After changing the Frankel grade into numbers (Frankel grade A was changed as 1 and Frankel grade $\mathrm{E}$ as 5), the pre-operative neurological insult was the highest in fracture AO- type C (1.46 \pm 0.78$)$, and the least neurological insult was in AO-type A $(3 \pm 0)$. At final follow-up, the neurological insult was still the highest in fracture AO-type C (2.23 \pm $1.3)$, followed by AO-type A $(3 \pm 0)$ (no changes in the degree of insult). The least neurological insult was observed in AO-type B (3.69 \pm 1.08$)(p<0.001)$. The best neurological recovery was observed in AO-type B (40\%), followed by AO-type C (21\%), and lastly AO-type A (0\%) (Table 2).

Table (2): Relation between AO fracture pattern and neurological status.

\begin{tabular}{|c|c|c|c|c|}
\hline & \multicolumn{3}{|c|}{ AO classification } & \multirow{2}{*}{$\begin{array}{c}p- \\
\text { value }\end{array}$} \\
\hline & $\begin{array}{c}\mathrm{A} \\
\text { Mean } \pm \mathrm{Sd}\end{array}$ & $\begin{array}{c}\text { B } \\
\text { Mean } \pm S d\end{array}$ & $\begin{array}{c}\text { C } \\
\text { Mean } \pm S d\end{array}$ & \\
\hline $\begin{array}{l}\text { - Pre-operative } \\
\text { Neurology }\end{array}$ & $3 \pm 0$ & $2.78 \pm 1.02$ & $1.46 \pm 0.78$ & 0.000 \\
\hline $\begin{array}{l}\text { - Neurology at final } \\
\text { follow-up visit } \\
\text { - Recovery } \\
\text { percentage }(\%)\end{array}$ & $3 \pm 0$ & $3.69 \pm 1.08$ & $2.23 \pm 1.3$ & 0.001 \\
\hline
\end{tabular}

Relation of fracture level and neurological insult:

The severity of pre-operative neurologic insult was the greatest in thoracic spine (T1 to T10) fractures followed by lumbar spine (L2 to L5) fractures and the least pre-operative neurologic compromise observed with TL junction (T11, T12, and L1) fractures. At the final follow-up, the severity of neurologic compromise was the greatest in thoracic spine fractures followed by thoracolumbar junction fractures and the least neurologic insult was observed with lumbar fractures.

The percentage of neurologic recovery was significantly the worst in thoracic spine fractures (0\%), followed by thoracolumbar junction fractures (34\%). The best neurological recovery was in the lumbar spine fractures $(46 \%)$ (Table 3 ).

Relation between canal compromise and neurological evaluation:

Mid-sagittal diameter improved from preoperative score $(49.17 \pm 28.32)$ to $(17.17 \pm 19.79)$ at postoperative CT scan. Canal compromise range decreased postoperatively by $32 \%$.

No relation was found between degree of canal compromise and neurological deficit of the patients neither pre-operatively $(p=0.386)$ nor in final follow-up $(p=0.405)$.

Relation between canal decompression and neurological evaluation:

The 32 patients $(53.3 \%)$ who underwent canal decompression (laminectomy) showed 39\% neurological recovery while the remaining $28(46.7 \%)$ who don't underwent canal decompression showed relatively less neurological recovery (25\%) with no significant difference (Table 4).

Table (3): Relation of fracture level and neurological insult.

\begin{tabular}{|c|c|c|c|c|}
\hline \multirow[b]{2}{*}{ Frankel points } & \multicolumn{3}{|c|}{ Level of fractured vertebrae } & \multirow{2}{*}{$\begin{array}{c}p- \\
\text { value }\end{array}$} \\
\hline & $\begin{array}{c}\text { Thoracic } \\
\text { Mean } \pm \text { Sd }\end{array}$ & $\begin{array}{l}\text { TL Junction } \\
\text { Mean } \pm S d\end{array}$ & $\begin{array}{c}\text { Lumbar } \\
\text { Mean } \pm \text { Sd }\end{array}$ & \\
\hline $\begin{array}{l}\text { - Pre-operative } \\
\text { Neurology }\end{array}$ & $1 \pm 0$ & $2.71 \pm 1.1$ & $2.43 \pm 0.85$ & 0.003 \\
\hline $\begin{array}{l}\text { - Post-operative } \\
\text { Neurology at final } \\
\text { follow-up }\end{array}$ & $1 \pm 0$ & $3.54 \pm 1.19$ & $3.64 \pm 0.74$ & 0.000 \\
\hline $\begin{array}{l}\text { - Recovery } \\
\text { percentage }(\%)\end{array}$ & 0 & 34 & 46 & \\
\hline
\end{tabular}

* : Statistically significant difference $(p<0.05)$.

**: Highly statistically significant difference $(p<0.01)$.

Table (4): Relation between canal decompression and neurological evaluation.

\begin{tabular}{llll}
\hline \multirow{2}{*}{ Frankel points } & \multicolumn{2}{c}{ Decompression } & $p$ - \\
\cline { 2 - 3 } & \multicolumn{1}{c}{$\begin{array}{c}\text { No } \\
\text { Mean } \pm \text { SD }\end{array}$} & $\begin{array}{c}\text { Yes } \\
\text { Mean } \pm \text { SD }\end{array}$ & value \\
\hline - Pre-operative & $2.29 \pm 1.3$ & $2.69 \pm 0.86$ & 0.159 \\
- Final follow-up & $3.04 \pm 1.57$ & $3.63 \pm 0.83$ & 0.070 \\
- Recovery percentage $(\%)$ & 25 & 39 & \\
\hline
\end{tabular}

* : Statistically significant difference $(p<0.05)$

$* *$ : Highly statistically significant difference $(p<0.01)$.

\section{Discussion}

In the current study 60 patients with thoracic, thoracolumbar and lumbar spine fractures combined with neurologic deficit were treated with transpedicular screw fixation in the Trauma Unit of Assiut University Hospital from January 2016 till June 2017.

The most fractured level in this study was L1 $(38.3 \%)$, as well as in Kaneda et al., study [15] $(50 \%)$. This is due to the anatomical and biomechanical changes that occur in this region "the transition zone".

In the current study two patients $(3.3 \%)$ out of 60 were type A, 45 type B (75\%) and 13 type C $(21.7 \%)$. These results are not comparable with the results of Mauro et al., study [16], in which fractures were assessed according to AO classifi- 
cation and 41 patients $(70.69 \%)$ out of 58 were type A, 5 type B (8.62\%), and 12 type C (20.7\%).

Also in that study, neurological evaluation at admission, according to ASIA grading system, showed 17 patients out of $58(29.3 \%)$ were at grade A, 11 (19\%) grade B, $10(17.2 \%)$ grade C and 20 $(34.5 \%)$ grade D. Forty-two patients $(72.4 \%)$ had improvement in neurologic function at 1 -year follow-up. Comparable results were reported in the current study as neurological evaluation at admission, according to Frankel classification, showed that 12 patients out of $60(20 \%)$ were grade D, $22(36.6 \%)$ grade C, $10(16.6 \%)$ grade B and $16(26.6 \%)$ grade A. Thirty nine patients of 60 $(65 \%)$ had improvement in neurologic function during the duration of the study.

Less neurological improvement was observed in the study of Deuk et al., [17] who reported improvement in 17 cases out of thirty nine (43.5\%).

Regarding relation between fracture pattern and neurological status and recovery, the current study showed that the greatest neurological insult was with the fracture pattern AO-type $\mathrm{C}$ preoperatively and at last follow-up. However the worst neurological recovery at final follow-up was with AO-type A fractures (0\%). This may be attributed to the small number of patients in this fracture pattern (two patients only). The best neurological recovery was with AO-type B fractures (40\%) followed by AO-type $\mathrm{C}$ fractures $(21 \%)$.

In the study of Moon et al., [18], the initial Frankel grading showed that 14 patients out of 38 were Grade D, 9 patients were Grade C, 2 patients were Grade B and 13 patients were Grade A. The severity of neurologic compromise pre-operatively and at the final follow was higher in the fracturedislocation than burst fracture. However, the neurologic recovery for Frankel grade, ASIA sensory and ASIA motor ratings was similar between burst fracture and fracture-dislocation.

Also in that study, the severity of pre-operative neurologic compromise was high in thoracic spinal fractures (T3-T10) and low in lumbar spinal fractures (L2-L4). The neurologic recovery was greater in the lumbar spinal fractures than in the thoracic spinal fractures.

Comparable results were noticed in the current study, as the severity of pre-operative neurologic insult was significantly the highest in thoracic spine fractures followed by lumbar spine fractures, and the least was observed in thoracolumbar junction (T1 1, T12 \& L1). Similarly, the best neurolog- ical recovery was with lumbar region fractures (46\%) followed by thoracolumbar junction fractures (34\%). No improvement detected with thoracic spine fractures.

Regarding canal compromise, Mohanty et al., [19] reported in this study that the mean extent of spinal canal compromise in patients with neurological deficits was $(50 \%)$, whereas it was (36\%) in those with no deficit. The difference between the extent of canal compromise and the severity of neurological deficit at the thoracolumbar and lumbar spine was not significant ( $p=0.08$ ). Also Benson et al., [20] reported that there was no correlation between the degree of canal compromise and any clinical symptoms. Similar results were noticed in this study. This may be attributed to the fact that spinal cord injury occurs at the time of trauma rather than being a result of pressure from fragments persisting in the canal.

Considering return to work (50\%) of patients can return to work in the current study. In McLain RF study [21], (70\%) of patients returned to work, and an additional (8\%) were capable of work despite remaining unemployed.

\section{References}

1- ALIGIZAKIS A., KATONIS P., STERGIOPOULOS K., et al.: Functional outcome of burst fractures of the thoracolumbar spine managed non-operatively, with early ambulation, evaluated using the load sharing classification. Acta Orthop. Belg., 68 (3): 279-87, 2002.

2- HU R., MUSTARD C.A. and BURNS C.: Epidemiology of incident spinal fracture in a complete population. Spine, 21: 492-9, 1996.

3- WINKLER E.A., YUE J.K., BIRK H., et al.: Perioperative morbidity and mortality after lumbar trauma in the elderly. Neuro. Surg. Focus., 39 (4): E2, 2015.

4- WATERS R.L., ADKINS R.H. and YAKURA J.S.: Definition of complete spinal cord injury. Paraplegia, 9: 573$81,1991$.

5- BRAVO P., LABARTA C., ALCARAZ M.A., et al.: An assessment of factors affecting neurological recovery after spinal cord injury with vertebral fracture. Paraplegia, 34: 164-6, 1996.

6- CENGIZ S.L., KALKAN E., BAYIR A., et al.: Timing of thoracolumber spine stabilization in trauma patients; impact on neurological outcome and clinical course. A real prospective (rct) randomized controlled study. Arch. Orthop. Trauma. Surg., 128: 959-66, 2008.

7- POLLARD M.E. and APPLE D.F.: Factors associated with improved neurologic outcomes in patients with incomplete tetraplegia. Spine, 28: 33-9, 2003.

8- KNOP C., BLAUTH M., BÜHREN V., et al.: Surgical treatment of injuries of the thoracolumbar transition. 1: Epidemiology, 102: 924-35, 1999. 
9- McCORMACK H.M., HORNE D.J. and SHEATHER S.: Clinical applications of visual analogue scales: A critical review. Psychol. Med., 18: 1007-19, 1988.

10- FRANKEL H.L., HANCOCK D.O., HYSLOP G., et al.: The value of postural reduction in the initial management of closed injuries of thespine with paraplegia and tetraplegia. I. Paraplegia, 7: 179-92, 1969.

11- KEPLER C.K., VACCARO A.R., SCHROEDER G.D., et al.: The thoracolumbar AO Spine injury score. Glob. Spine J., 6: 329-34, 2016.

12- TRAFTON P. and BOYD C.: Computed tomography of thoracic and lumbar spine injuries. J. Trauma, 24: 506$15,1984$.

13- FAIRBANK J.C. and PYNSENT P.B.: The Oswestry Disability Index. Spine, 25 (22): 2940-52, 2000.

14-McCORMACK T., KARAIKOVIC E. and GAINES R.W : The load sharing classification of spine fractures. Spine, 19: 1741-4, 1994

15-KANEDA K., ABUMI K. and FUGIYA M.: Burst fractures with neurological deficit of the spine spine, 9: 798, 1984.

16- MAURO DOBRAN, MAURIZIO IACOANGELI, LUCIA GIOVANNA, et al.: Neurological outcome in a series of
58 patients operated for traumatic thoracolumbar spinal cord injuries. Surg. Neurol. Int., 5 (7): S329-S332, 2014.

17- DEUK SOO JUN, CHANG HUN YU and BYOUNG GEUN AHN: Posterior direct decompression and fusion of the lower thoracic and lumbar fractures with Neurological Deficit. Asian Spine Journal, 5 (3): 146-54, 2011.

18- MOON SOO PARK, SEONG-HWAN MOON, JAE-HO YANG, et al.: Neurologic Recovery According to the Spinal Fracture Patterns by Denis Classification. Yonsei Med. J., 54 (3): 715-9, 2013.

19- MOHANTY S.P., BHAT N.S., ABRAHAM R., et al.: Department of Orthopaedics, Kasturba Medical College, Manipal, Karnataka, India Journal of Orthopaedic Surger, 16 (1): 203, 2008.

20- BENSON D.R., BURKUS J.K., MONTESANO P.X., et al.: Unstable thoracolumbar and lumbar burst fractures treated with the AO fixateur interne. J. Spinal Disord., 5: 335-43, 1992

21- McLAIN R.F., BURKUS J.K. and BENSON D.R.: Segmental instrumentation for thoracic and thoracolumbar fractures: Prospective analysis of construct survival and five-year follow-up. The Spine Journal, 1 (5): 310-23, 2001 .

\section{التعافى من الإصابة العصبية فى مرضى كسور الفقرات الظهرية والقطنية بالنسبة إلى طبيعة الكسرو}

• كسور الفقرات الظهرية والقطنية هي الإصابة الآكثر شيوعا فى الهيكل العظمى المحوىى وتمثل حوالى ـ9٪ من جميع كسود العمود الفقرى.

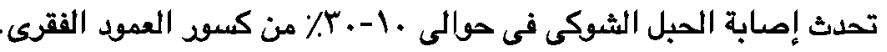

• تهدف هذه الدراسة لتحليل العلاقة بين نمط الكسر وفقا لتصنيف AO والتعافى العصبى بعد إجراء جراحة تثبيت لكسود الفقرات الظهرية

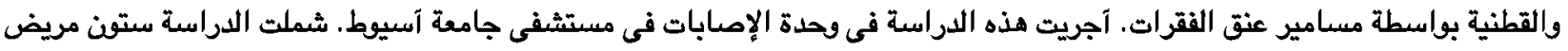

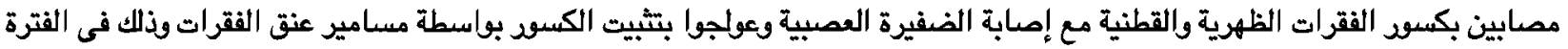

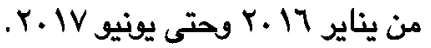

• تراوحت آعمار المرضى بين 17 و.7 عاما ، كسر الفقرة القطنية الآولى كان هو الكسر الآكثر ثيوعا والسقوط من علو كان المسبب لآكثر

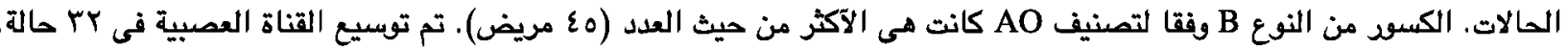

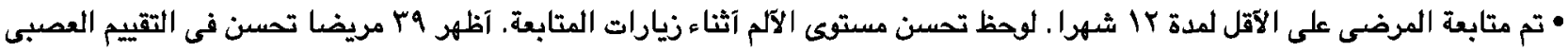

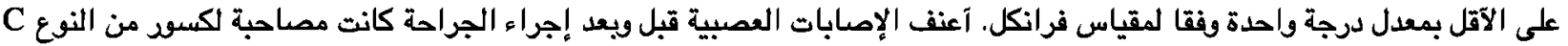
وفقا لتصنيف AO وفى كسود الفقرات الظهرية.

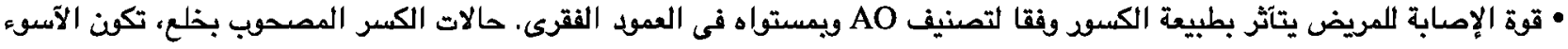
بالنسبة لإصابة العصبية المصاحبة، درجة التصسن تكنف آقل بالنسبة لمرضى كسور الفقرات الظهرية عن كسود الفقرات القطنية آو منطقة إتصال الفقرات الظهرية والقطنية.

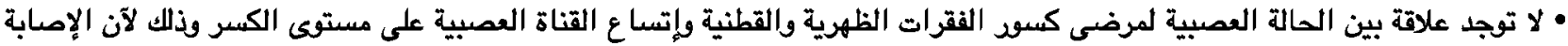

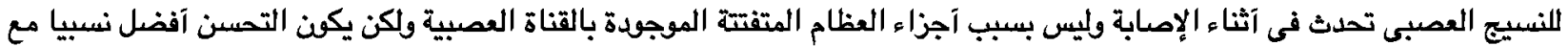

